\title{
THE QUALITY OF MARRIAGE IN FUNCTION OF SATISFACTION WITH LIFE, SATISFACTION WITH WORK, DEPRESSION AND ALTRUISM ${ }^{1}$
}

\author{
Jelisaveta Todorović, Miljana Spasić Šnele, \& Marina Hadži Pešić \\ Faculty of Philosophy University of Niš (Serbia)
}

\begin{abstract}
There are multiple contributors that help maintain and improve partner relationships in marriage, however, there are also those that cause the quality of marriage to decrease. As a result, the researched subject matters often were length of marriage, health of partners, personality traits, and number of children. One of the research goals, conducted in 2018 using PORPOS-3 battery, was to examine if satisfaction with work, satisfaction with life, depression, and altruism are significant predictors of different dimensions of marriage quality. Quality of marriage was measured using shorten scale Dyadic Adjustment Scale (DAS, Spanier, 1976) that estimate dyadic adaptability. Applying factor analysis three factors of the DAS scale were extracted: dyadic consensus $(\alpha=0.889)$, satisfaction with marriage $(\alpha=0.847)$, and risks for marriage stability $(\alpha=0.758)$. Altruism was measured using the scale that represents combination of the Altruism scale (Raboteg-Šaric, 2002) and the Alzam scale (Cekrlija, Turjačanin \& Puhalo, 2004) $(\alpha=0,938)$. Participants evaluated the level of satisfaction with life and satisfaction with work on a scale from 1 (for completely unsatisfied) to 10 (completely satisfied). Depression was measured with scale Patient health Questionnaire (PHQ-9) $(\alpha=0,862)$. The sample consisted of couples who are married or in a relationship $(\mathrm{N}=900)$, mean age $41(\mathrm{SD}=12,471)$ (aged 19 to 79), living in 37 urban and rural locations distributed through 20 administrative districts of Serbia. Hierarchical regression analyses were applied, whereby at the first step, we entered sociodemographic variables (age, education, number of children, gender), and at the second step we entered satisfaction with life and work, depression, and altruism. Only the predictors that were significantly correlated with the criterion were included in the models. Depression, satisfaction with life, age, and satisfaction with work were significant predictors of criterion variable dyadic consensus $\left(F(7,733)=26,310, R^{2}=, 201\right.$, $p=, 000)$; depression, satisfaction with life, age, gender, and altruism were significant predictors of criterion variable risks for marriage stability $\left(F(6,744)=30,332, R^{2}=, 197, p=, 000\right)$, and depression, age, satisfaction with life, altruism, satisfaction with work, and the number of children were significant predictors of criterion variable satisfaction with marriage $\left(F(7,741)=30,657, R^{2}=, 225, p=, 000\right)$. Depression increased risks for marriage stability (risks entail disagreement and divorce discussion), and it negatively affected satisfaction with marriage and dyadic consensus. Altruism did not have a significant impact on dyadic consensus, but it influenced satisfaction with marriage and reduced risk of marriage stability. When lower satisfaction with life, risks of marriage stability increased. Satisfaction with work had a significant but low impact on dyadic consensus and satisfaction with marriage.
\end{abstract}

Keywords: Quality of marriage, satisfaction with life, satisfaction with work, depression, and altruism.

\section{Introduction}

Based on the literature regarding marital satisfaction, marriage quality and happiness in marriage, Spanier (1976) has developed a model of marital quality that encompasses three main domains. The first group consists of variables that people bring in with themselves into the marriage, e.g. self-esteem, mental health, abilities, and the author calls them personal resources. The second group refers to satisfaction with lifestyle, including composition of household, satisfaction with spouse's work, support from friends, relatives and the community. The third group refers to rewards from marital interaction, including emotional valuing, effectivity of communication, agreement in roles, amount of interaction and positive attitude towards spouse (Čudina Obradović \& Obradović, 2006). Spanier (1976) defines marital quality as mutual/reciprocal adaptation of both partners.

Karney and Bradbury (1995) conducted metanalysis with 110 longitude studies, including 10.000 married couples. The results showed that the most predictive variable of women's perception of

${ }^{1}$ This paper is prepared as a part of the project Indicators and Models of Harmonization of Professional and Family Roles, No. 179002 funded by Ministry of Education, Science and Technological Development of Republic of Serbia. 
marriage stability is her own perception of quality of marriage, followed by her age, age when she married, sexual satisfaction in marriage, education, family income, etc. When it comes to men's perception of marriage stability, the most predictive variable was his sexual satisfaction in marriage, followed by his own perception of quality of marriage.

In order to examine importance some of the factors of personality when it comes to the quality of marriage, we decide to include altruism, depression, satisfaction with life and satisfaction with work. Altruism is a specific form of prosocial behavior that includes genuinely selfless behavior towards others, without vested interest. Altruism, which is manifested through care towards other people and behavior that contribute to their wellbeing, can have an important role in dyadic consensus in marriage (Joksimović, 1999). Satisfaction with life is one of components of personal wellbeing and is defined as global self-assessment of quality of life regarding own criterions, independent of some specific values, norms or goals (Vasić, Šarčević, \& Trogrlić, 2011).

Person who in generally more positively estimate life and have higher self-esteem, more positively value intimate relationships and marriage (Todorović, 2005; Vidanović, Todorović, \& Hedrih, 2006; Matejević \& Todorović, 2012). General satisfaction with life is personal component that can contribute to satisfaction with marriage. In many researches, depression is perceived as a result of impaired quality of marriage and intimate relationships, but on the other hand, depression, as well other mental-health problems could influence quality of marriage (Čudina Obradović \& Obradović, 2006). Depression manifests through experience of sadness and hopelessness, feeling of disappointment. The person does not enjoy anything, loses interest and energy. He/she gives up on normal activities and has problems with concentrate and remembering. Depression is usually accompanied by physical symptoms, poor and insufficient sleep, poor appetite, low self-esteem and low global satisfaction with life satisfaction. Satisfaction with work is especially indicated as an important parameter of personal satisfaction, which can spillover onto the quality of marriage. In Obaradović and Čudina-Obradović (2013) study, stress at work was shown to indirectly affect the quality of marriage. The model in which the mediating variable was marital stress was the strongest. According to the results of this research, wives experience negative spillover more intensively, as well as marital strain and depression.

The aim of present research was to examine whether satisfaction with work, satisfaction with life, depression and altruism represent significant predictors of dimensions of quality of marriage?

\section{Method}

\subsection{Sample}

The total sample of research is comprised of 1258 participants living in 37 urban and rural locations distributed through 20 administrative districts of Serbia (Hedrih \& Ćirović, 2019). Locations were either a part of a larger city or strings of smaller settlements and villages. The results presented in this study refer to the sample of persons who stated that they were married or in a romantic relationship, representing 900 participants with mean age of $41(\mathrm{SD}=12,471)$ (aged 19 to 79$)$. Out of that number 567 were women, and 315 men. When it comes to the level of education 2 participants did not finish elementary school $(0,2 \%), 21(2,3 \%)$ had finished elementary school, 381 finished high school $(42,3 \%)$, 131 had college degree $(14,6 \%), 342$ had university degree $(38 \%)$, and 5 had Ph.D. degree $(0,6 \%) .274$ participants did not have children (30,4\%), $184(20,4 \%)$ had one child, 365 reported to have two children $(40,6 \%), 56$ to have three children $(6,2 \%), 7$ to have four children $(0,8 \%), 3$ to have 5 children $(0,3 \%)$, and participants reported to have 6 children $(0,1 \%)$.

\subsection{Variables and instruments}

Quality of marriage was measured with shortened DAS scale (Spanier, 1976), that estimate dyadic adaptability. The shortened version has 16 questions. Applying factor analysis three factors of the DAS scale were extracted: dyadic consensus ("Please, indicate in what degree your partner and you agree when it comes to family finances, expression of emotions, etc.") $(\alpha=0.889)$, satisfaction with marriage ("How often following situations happen between your partner and you: laugh together, etc.") $(\alpha=0.847)$, and risks for marriage stability ("How often do you talk or think about divorce, separation or ending the relationship") $(\alpha=0.758)$. The scale dyadic consensus consisted of six questions, scale risks for marriage stability of three, and satisfaction with marriage of seven questions.

Altruism was measured using the scale that represents combination of the Altruism scale (Raboteg-Saric, 2002) and the Alzam scale (Cekrlija, Turjačanin \& Puhalo, 2004), with 12 questions ("I feel excellent when I can help the other person") $(\alpha=0,938)$.

The level of satisfaction with life was measured with a question: "On the scale from 1 (for completely unsatisfied) to 10 (completely satisfied) rate the level of your satisfaction with life in general"'.

The level of satisfaction with work was measured with a question "On the scale from 1 (for completely unsatisfied) to 10 (completely satisfied) rate the level of your satisfaction with your present job." 
Depression was measured with scale Patient health Questionnaire PHQ-9 ("In last 2 weeks, how often have you been bothered by any of the following problems: weak interest or satisfaction to do something, etc.”). The scale consisted of nine questions. Cronbach $\alpha$ on our sample was 0,862 .

\section{Results}

According to the Table 1 we can see that dyadic consensus was in negative moderate correlation with depression, in positive weak correlation with satisfaction with life, satisfaction with work, altruism and education, and in negative weak correlation with age and number of children. Risks for marriage stability was in positive moderate correlation with depression, in negative weak correlation with satisfaction with life, altruism, satisfaction with work, age, and in weak positive correlation with gender. Satisfaction with marriage was in moderate negative correlation with depression, and in negative weak correlation with age, and number of children, and in positive weak correlation with satisfaction with work and life, altruism and age.

Table 1. Descriptive statistics and correlation between variables.

\begin{tabular}{|c|c|c|c|c|c|c|c|c|c|c|}
\hline & 4. & 5. & 6. & 7. & 8. & 9. & 10. & 11. & $\mathrm{M}$ & SD \\
\hline $\begin{array}{l}\text { 1. Dyadic } \\
\text { consensus }\end{array}$ &, $109^{* *}$ &, $279^{* *}$ &,$- 366^{* *}$ &, $104^{* *}$ &,$- 139^{* *}$ &, $074^{*}$ &,$- 088^{* *}$ &,- 062 & 3,89 & ,92 \\
\hline $\begin{array}{l}\text { 2. Risks for } \\
\text { marriage } \\
\text { stability }\end{array}$ &,$\overline{-}^{* *}$ &,$- 231^{* *}$ &, $403^{* *}$ &,$- 158^{* *}$ &,$- 089^{* *}$ &,- 037 &,- 036 &, $093^{* *}$ & ,97 &, 82 \\
\hline $\begin{array}{l}\text { 3.Satisfaction } \\
\text { with } \\
\text { marriage }\end{array}$ &, $108^{* *}$ &, $247^{* *}$ &,$- 328^{* *}$ &, $162^{* *}$ &,$- 270^{* *}$ &, $114^{* *}$ &,$- 186^{* *}$ &,- 059 & 3,88 & ,91 \\
\hline $\begin{array}{l}\text { 4.Satisfaction } \\
\text { with work }\end{array}$ & l &, $490^{* *}$ &,$- 232^{* *}$ &, $073^{*}$ &,$- 103^{* *}$ &, $156^{* *}$ &,$- 070^{*}$ &,- 018 & 6,72 & 2,37 \\
\hline $\begin{array}{l}\text { 5.Satisfaction } \\
\text { with life }\end{array}$ & & l &,$- 275^{* *}$ & ,043 &,$- 162^{* *}$ &, $222^{* *}$ &,$- 087^{*}$ & ,029 & 7,26 & 1,99 \\
\hline 6.Depression & & & 1 &,$- 201^{* *}$ &,- 048 &,$- 109^{* *}$ & $-0,042$ & $071^{*}$ &, 62 & ,57 \\
\hline 7. Altruism & & & & 1 & ,008 &, 054 & 0,027 &, $090^{* *}$ & 4,44 &, 67 \\
\hline 8. Age & & & & & 1 &,$- 116^{* *}$ &, $534^{* *}$ &,$- 105^{* *}$ & & \\
\hline 9. Education & & & & & & 1 &,$- 194 * *$ &, 005 & & \\
\hline $\begin{array}{l}\text { 10. Number } \\
\text { of children }\end{array}$ & & & & & & & I &,- 194 & & \\
\hline 11. Gender & & & & & & & & / & & \\
\hline
\end{tabular}

Hierarchical regression analyses were used to estimate the relative contributions of the independent variables (satisfaction with life and work, depression, altruism, age, level of education, number of children and gender) to the prediction of criterion variables (dyadic consensus, risks for marriage stability and satisfaction with marriage). In that way, we examined conjoint and separate contributions of predictors to criterion variables. At the first step, we entered sociodemographic variables (age, education, number of children, gender), and at the second step we entered satisfaction with life and work, depression, and altruism. Only the predictors that were significantly correlated with the criterion were included in the model (Table 1).

Table 2. Hierarchical regression analysis (method Enter), criterion variable Dyadic consensus.

\begin{tabular}{|c|c|c|c|c|c|c|c|c|c|}
\hline & \multicolumn{9}{|c|}{ Dyadic consensus } \\
\hline & Predictors & $\beta$ & $\mathrm{p}$ & Tolerance & VIF & $\mathrm{R}^{2}$ & $\mathrm{p}$ & $\Delta \mathrm{R}^{2}$ & $\mathrm{p}$ \\
\hline \multirow{3}{*}{ I } & Age &,- 148 &, 000 &, 753 & 1,328 & \multirow{3}{*}{, 023} & \multirow{3}{*}{, 001} & & \\
\hline & Education &, 034 & ,362 & 958 & 1,044 & & & & \\
\hline & Number of children &, 012 & ,773 & ,734 & 1,363 & & & & \\
\hline \multirow{7}{*}{ II } & Age &,- 116 &, 003 & ,732 & 1,366 & \multirow{7}{*}{,201 } & \multirow{7}{*}{, 000} & \multirow{7}{*}{, 178} & \multirow{7}{*}{, 00} \\
\hline & Education &,- 025 & ,469 & ,921 & 1,086 & & & & \\
\hline & Number of children &,- 017 & ,654 & ,730 & 1,369 & & & & \\
\hline & Satisfaction with work &,- 104 & ,008 & ,722 & 1,385 & & & & \\
\hline & Satisfaction with life & ,240 & ,000 & ,695 & 1,438 & & & & \\
\hline & Depression &,- 333 & ,000 &, 865 & 1,156 & & & & \\
\hline & Altruism &, 019 & ,572 & ,949 & 1,054 & & & & \\
\hline
\end{tabular}


In table 2 we can see that the second model was statistically significant $(F(7,733)=26,310$, $p=, 000)$, and explained $20.1 \%$ of variance of criterion variable dyadic consensus. Depression, satisfaction with life, age, and satisfaction with work were significant predictors.

Table 3. Hierarchical regression analysis (method Enter), criterion variable Risks for marriage stability.

\begin{tabular}{|c|c|c|c|c|c|c|c|c|c|}
\hline & \multicolumn{9}{|c|}{ Risks for marriage stability } \\
\hline & Predictors & $\beta$ & $\mathrm{p}$ & Tolerance & VIF & $\mathrm{R}^{2}$ & $\mathrm{P}$ & $\Delta \mathrm{R}^{2}$ & $\mathrm{p}$ \\
\hline \multirow{2}{*}{ I } & Age &,- 079 & ,031 & ,994 & 1,006 & \multirow{2}{*}{,015 } & \multirow{2}{*}{003} & & \\
\hline & Gender &, 090 &, 014 & ,994 & 1,006 & & & & \\
\hline \multirow{6}{*}{ II } & Age &,- 093 &, 006 & 961 & 1,040 & \multirow{6}{*}{, 197 } & \multirow{6}{*}{, 000} & \multirow{6}{*}{,181 } & \multirow{6}{*}{, 000} \\
\hline & Gender &, 074 &, 027 & 971 & 1,030 & & & & \\
\hline & Satisfaction with work &, 054 &, 160 &, 729 & 1,372 & & & & \\
\hline & Satisfaction with life &,- 175 &, 000 & ,709 & 1,411 & & & & \\
\hline & Depression &, 345 &, 000 & 854 & 1,171 & & & & \\
\hline & Altruism &,- 070 &, 041 & ,932 & 1,073 & & & & \\
\hline
\end{tabular}

Table 3 shows that the second model was statistically significant $(F(6,744)=30,332, p=, 000)$, and explained $19,7 \%$ of variance of criterion variable risks for marriage stability, whereby significant predictors were depression, satisfaction with life, age, gender, and altruism.

Table 4. Hierarchical regression analysis (method Enter), criterion variable Satisfaction with marriage.

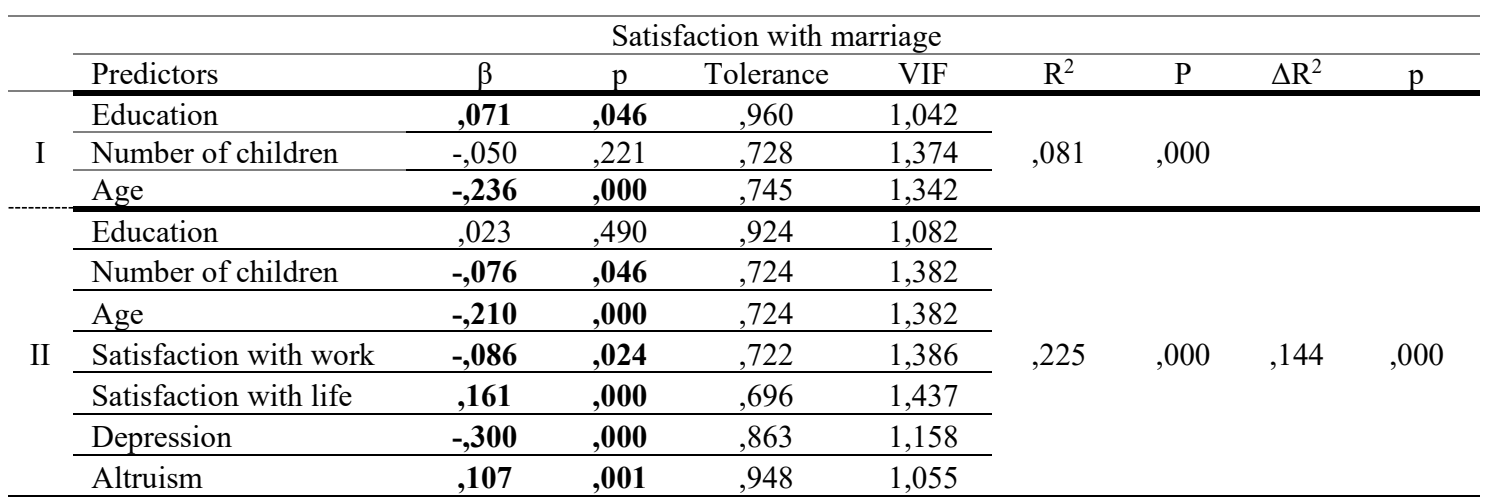

According to the table 4 we can see that the second model is statistically significant $(F(7,741)=30,657, p=, 000)$, and explained $22.5 \%$ of variance of criterion variable satisfaction with marriage. Depression, age, satisfaction with life, altruism, satisfaction with work, and number of children were significant predictors.

\section{Discussion}

Depression and satisfaction with life represent factors of personality which mostly contribute to the quality of marriage in present research. Depression increased risks for marriage stability (risks entail disagreement and divorce discussion), and it negatively affected satisfaction with marriage and dyadic consensus. On the other hand, satisfaction with life increased dyadic consensus, contributing to the agreement of partners when it comes to different issues of joint life, as well as satisfaction with marriage, and decreased risks for marriage stability. Altruism did not have a significant impact on dyadic consensus, but it influenced satisfaction with marriage and reduced risk for marriage stability. Satisfaction with work had a significant, but inversive and low impact on dyadic consensus and satisfaction with marriage, but when it comes to the risk of marriage stability this parameter is not significant. In line with that it could be said that satisfaction with work decreases the consensus between partners when it comes to arrangements related to different joint activities, as well as overall satisfaction with marriage, most likely due to the fact that partners are more preoccupied by work than with partnership. With age both dyadic consensus and satisfaction with marriage decrease, but also and risks for marriage stability. Colossal changes and divorce are avoided in older age, regardless of increase in marriage dissatisfaction. 


\section{Conclusion}

Findings showed that personal characteristics, e.g. depression and satisfaction with life had significant contribution to all dimensions of marriage quality, compared to objective indicators, e.g. age, number of children, education, gender, but also and with satisfaction with work.

\section{References}

Čudina Obradović, M. \& Obradović, J. (2006). Psihologija braka i obitelji [Psychology of marriage and family]. Zagreb: Golden marketing - Tehnička knjiga.

Hedrih, V., \& Ćirović, N. (2019, September). Symposium study of work-family relations in Serbia 2018-2019. Paper presented at International Conference, $15^{\text {th }}$ Days of applied psychology Psychological research and practice, Niš, Serbia. Abstract retrieved from http://www.psihologijanis.rs/dpp/arhiva/DPP2019.pdf

Joksimović, S. (1999). Razvoj i podsticanje altruizma mladih [Development and encouragement of altruism in youth]. Nastava $i$ vaspitanje, 48(5), 605-616

Karney, B. R. \& Bradbury, T.N. (1995). The longitudinal course of marital quality and stability: A review of theory, method, and research. Psychological bulletin, 118, 3-34.

Matejević, M.\& Todorović, J. (2012). Funkcionalnost porodičnih odnosa i kompetentno roditeljstvo [Functionality of family relations and competent parenting]. Niš: Filozofski fakultet.

Obradović, J. \& Čudina-Obradović, M. (2013). Work Stress and Marital Quality in Dual Earner Couples: A Test of Three Mediation Models, Društvena istraživanja, 22(4) 673-691.

Spanier, G. B. (1976). Measuring dyadic adjustment: New scales for assessing the quality of marriage and similar dyads. Journal of Marriage and the Family, 15-28.

Todorović, J. (2005). Vaspitni stilovi roditelja i samopoštovanje adolescenata. [Parenting styles and adolescent self-esteem]. Niš: Prosveta.

Vasić, A., Šarčević, D., Trogrlić, A. (2011). Zadovoljstvo životom u Srbiji. [Satifscation with life in Serbia]. Primenjena psihologija, 2011/2, 151-177

Vidanović, S., Todorović, J., \& Hedrih, V. (2006). Porodica i posao, izazovi i mogućnosti. [Family and work, challenges and opportunities]. Niš: Filozofski fakultet. 